\section{ECONOMICS}

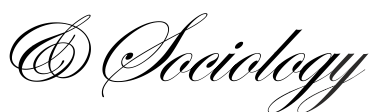

\title{
BREXIT AND EU COMMON AGRICULTURAL POLICY: THE POSSIBLE CONSEQUENCES FOR LITHUANIA
}

\author{
Artiom Volkov, \\ Lithuanian Institute of Agrarian \\ Economics, \\ Vilnius, Lithuania \\ E-mail:artiom.volkov@laei.lt \\ Tomas Baležentis, \\ Lithuanian Institute of Agrarian \\ Economics, \\ Vilnius, Lithuania \\ E-mail:tomas.balezentis@laei.lt \\ Mangirdas Morkūnas, \\ MykolasRomeris University, \\ Vilnius, Lithuania \\ E-mail: \\ morkunas.mangirdas@mruni.eu \\ Dalia Streimikiene, \\ Lithuanian Institute of Agrarian \\ Economics, \\ Vilnius, Lithuania \\ E-mail:dalia@mail.lei.lt
}

Received: November, 2018

1st Revision: March, 2019

Accepted: June, 2019

DOI: $10.14254 / 2071-$

789X.2019//12-2/2

JEL Classification:Q14, Q18
ABSTRACT. This paper examines the possible Brexit scenarios and their impacts on the Common Agricultural Policy (CAP) of the European Union (EU) with particular focus on Lithuania. The paper outlines the scientific discourse on the imminent modifications of the CAP after the Brexit along with changes in the EU budget. The paper was prepared during the beginning of Brexit negotiations, with withdrawal terms not being publicly disclosed. Thus, the most likely assumptions have been accepted in order to model the scenarios. The possible effects of Brexit on the agriculture of the small EU Member States are discussed taking the case of Lithuania as an example. The empirical analysis showed that, in the case of three different Brexitinduced CAP modifications, Lithuanian agricultural sector may lose $1 \%$ to $20 \%$ of financial support under the CAP direct payment mechanism. The corresponding loss under these scenarios is quantified for agricultural sectors of all the EU Member States.
Keywords: Brexit, common agricultural policy, scenario modelling, Lithuania.

\section{Introduction}

Even though the United Kingdom has not been a founder of either the European Steel and Coal Community or the European Economic Community, for more than four decades it had been one of the main architects of unified European economic body - European Union representing its second biggest economy, third most populous Member State (MS) and a solid net contributor to the EU budget of almost 8.5 billion GBP per year. The plausible exit of 
such an important integral EU part as UK is one of the most significant events in both EU and UK political and economic life in a generation, having a potential to generate long lasting profound social, economic, political, security effects for the whole World for many years to come. This process have attracted a wide scientific attention from both, public policy, political science and economic researchers providing various estimates and predictions about impending economic effects both to UK and EU MS. A pig part of scientific focus was put on secondary impacts, such as changes in FDI flow trajectories (Dhingra et al., 2016, Kierzenkowski et al., 2016; Bruno et al., 2016), transformations of economic activities due to restrictions to immigration (Ebell \& Warren, 2016; Owen \& Walter, 2017; Sorace \& Hobolt, 2018), the changing income distribution and possible negative GINI corrections across income groups (Breinlich et al., 2016). Although existing researches pay a very little attention to the way in which the possible British exit from EU are likely to impact the EU MS agricultural sector - the biggest beneficiary of the EU budget through the Common Agricultural Policy. That is more important, the new small EU MS and its agri-business future after UK exit is being left in a shadow of a scientific dispute. This paper is addressed to fulfil this scientific vacuum, providing insights on possible CAP modifications after British withdrawal from EU and the effect of these modifications to small new EU MS agricultural sectors economic viability.

This research features limitations related to the nature of the research object. Specifically, the paper was prepared during the beginning of Brexit negotiations, with withdrawal terms not being publicly disclosed. Thus, the most likely assumptions have been accepted in order to model the scenarios.

\section{Literature review}

\subsection{Theoretical discussion on the effect of Brexit onto CAP}

After June 23, 2016, when British citizens voted for leaving European Union (process, called Brexit) deciding, that benefits of remaining in a unified economic body of 28 European Union member states became overshadowed by the negative consequences arising from four main liberties of EU: free passage of capital, goods, services and labour force (the latter becoming the biggest concern), the ongoing scientific debate, dealing with the reasonableness and consequences of this decision. Although the consequences of this decision will be felt all over the World (Sampson, 2017; Simionescu et al., 2017; Simionescu, 2018), the EU, as the biggest UK trading partner will be amongst the most severely affected, with possible negative correction of its GDP by $0,5 \%$. It is clear that it is necessary to study the financial dependence of the countries and their financial markets inside the EU (Golab A., 2018). The first, who experienced the Brexit effect were financial institutions, facing up to ten times bigger capital requirements than during financial crisis of 2008-2009 (Carney, 2016). Other industries are to follow headed by agriculture (Dwyer, 2018).

It is clear and obvious that the new EU Member States agricultural sectors will be of those, that will be most seriously affected by Brexit too. Lithuania is not an exemption. It is not only it is dependent on trade relations both within the European Union, that has no restrictions (Britain is one of the main export partners) and with the Commonwealth states (trading partners what will be harder to reach after Brexit), but it is also very dependant and is heavily subsidised and regulated under the present Common Agricultural Policy (CAP) (Hubbard et al., 2018). The impact of Brexit on the agricultural sector is conditioned by the degree of future trade competitiveness (i.e. relative tariffs) and trade openness between EU and Britain (Szczepaniak, 2018; Vitunskiene \& Serva, 2015). It also depends on the status of the sub-sector concerned (agriculture, fishery, organic farming and etc.), but it is widely 
accepted, that it will negatively affect the conditions for agri-business in both UK and EU (McMahon, 2018). All the changes in the EU policy towards its agricultural sector will be reflected by the modifications of CAP, especially its financial support mechanism - direct payments system.

The have been different opinions about CAP and its influence on Member States agribusiness sectors. Besides its pros, such as substantially increased farmers income (Kiss, 2011), assured employment and viability of rural regions (Bartolini\&Viaggi, 2013), cohesion and lowering GINI gap (Bachtler\& Mendez, 2016), helped to eradicate land abandonment and etc., it also possess cons. Here it is of great importance to take into account the potential of land resources for agricultural enterprises (Kozhukhivska et al, 2018; Reiff et al., 2016). In the case of the new member states of the EU it can lead to the problem of excessive purchasing agricultural property by foreigners (Lizińska et al, 2017). It is widely accepted, that the Common Agricultural Policy has had an overall negative environmental impact on environmental quality, fostering the intensification of agriculture, increasing water and air pollution and accelerating the decline in farmland birds (Gravey, 2016). Some Brexit proponents and green activists (Grant, 2018) have expected changes in CAP after Brexit addressed to abovementioned challenges, although the opinion prevails, that EU will have to improve land use in order to keep the living standards of its farmers at a comparable level to ones before Brexit (Swinbank, 2016; Helm, 2017). The environmental standards will even perish, as the UK has been a consistent champion of CAP reform and pioneered environmental measures that have been taken-up and widely applied, generating benefits across the EU (Gravey, 2016).

In order to avoid negative impacts of Brexit onto new Member States agricultural sectors, a universal crisis management policy can be adopted. It is recommended to foster economic resilience in farm and other land management businesses by supporting versatile adaptation, increasing economic efficiency, business diversification, adding value and intergenerational transfer, investing into long - term partnerships in the value chain, shortening it, enhancing SME's networks in agriculture. In spite of the aforementioned measures, budget allocated for the CAP is to shrink. Such a perspective is being discussed by a wide range of agricultural economics scholars, such as: Boulanger \& Philippidis (2015); Matthews (2016); Nunez-Ferrer \& Rinaldi (2016); Haas \& Rubio (2017); Darvas \& Wolff (2018); Bateman \& Balmford (2018). There have been different estimates of decrease in the CAP budget following the Brexit. The amount estimated is 3 billion EUR - the sum that is being paid to CAP funding schemes by Britain, would disappear after Brexit. As this scenario is of a high probability, we have taken this into account modelling the impact of Brexit onto Lithuanian agricultural sector, naming this scenario CAP3. Indeed, the Brexit may affect the economic situation in EU in general (Busch \& Matthes, 2016; Bergin et al., 2017; Whymann \& Petrescu, 2017; Lawless \& Morgenroth, 2019). It is being argued, that if Britain leaves the EU without a trade agreement and soft backstop, when a trade between EU and Britain would reduce (including agri-food products), arising from the imposition of tariffs on almost all products (also to key Lithuanian agricultural export good - wheat), it negatively affects all EU Member States economies, thus resulting in lower budget revenues of respective Member States and reduced CAP budget by 10 billion EUR (Boulanger \&Philippidis, 2015; Darvas\& Wolf, 2018). This scenario is considered as a less desirable and termed CAP10.

There have also been suggestions that Brexit may produce economic benefits. Especially, in a soft Brexit scenario, where United Kingdom remains part of European Economic Area and enjoys the same common European market benefits as Norway (Dhingra et al., 2016). There is a possibility of changes to trading patterns, entrepreneurship and even encouraging new industries (Culkin \& Simons, 2019). All these changes would contribute to economic activities in the EU that may compensate the Brexit consequences. It would allow 
to allocate a slightly bigger part of the EU budget to CAP in order to keep direct payments on the same level. The possibility of the occurrence of this scenario is increased by the fact, that if the direct payments under the CAP would become lower, resulting a farming in less favourable areas becoming unprofitable. It may lead to situation when farmers exit their business in order to avoid losses, thus deepening the social problems in rural areas. All these possible scenarios will obviously have structural effects on the whole EU budget.

\subsection{Structural effect of Brexit on EU finances}

The impact of Brexit on EU finances is ambiguous. One of important challenges is the reorganization and redistribution of all Common property and commitments between the UK and the remaining EU members.

The EU's assets basically consist of financial assets (loans, cash), pre-financing amounts and properties and equipment. The EU's main liabilities include pension rights, future payment obligations related to multi-annual projects, borrowing operations (e.g. through the the European Financial Stabilisation Mechanism), provisions made to cover risks taken through loans and other financial instruments, and pending invoices (European Commission (2017a). As the documents of EU consolidated accountability shows, in 2015, the value of EU assets was 154 billion EUR while the liabilities amounted to 226 billion Euros. This means that the EU has more liabilities than assets (European Commission, 2016) and due to this reason, the UK will be required to pay the EU the so-called "divorce bill", the size of which will depend on the negotiation of Brexit. According to "Financial Times", Brexit may cost the United Kingdom from 20 to 60 billion EUR (Financial Times, 2017).

Since the government of the UK activated the article 50 until the end of March of 2017 (European Council, 2017), the UK is supposed to leave the EU in the middle of 2019, which is before the end of Multi-annual Financial Framework (MFF). However, withdrawal of the UK will not have one-off effects on the MS. Based on the state of progress of the negotiations with the UK under Article 50 of the Treaty on EU of the 2017 December $8^{\text {th }}$, following withdrawal from the EU, the UK will continue to participate in the EU programmes financed by the MFF for 2014-2020 until their closure, except for the programmes in which the UK did not participate before and those which can give rise to contingent liabilities the United Kingdom will not be liable for after withdrawal. Participation in EU programmes will require the UK and its beneficiaries to respect all relevant EU legal provisions (EuroposKomisija, 2017).

Despite the fact that the EU avoided one-off effects up to the year 2020, Brexit will have a huge impact on the size, components and financing of MFF after 2020. These structural changes are less relevant to Lithuania today but are significant to the EU. Firstly, the EU budget will be redistributed considering the constant MFF financing deficit which can be equal to the sum of UK's net contribution or less, depending on the Brexit terms of agreement. Secondly, UK's withdrawal and accordingly, decrease in the EU gross national income (GNI) may mean that the EU budget will significantly decrease in absolute value if the Council of the EU maintains its stance to keep the EU budget at $1 \%$ of EU GNI. Finally, Brexit will change the dynamics of budgetary negotiations in the EU Council. Termination of UK's net contributions will not only change the amounts of other member states contributions but can influence the internal dynamics within the coalition of net contributors (Haas, Rubio, 2017). Therefore, when reorganizing the EU budget after Brexit, the EU member states will need to come up and agree on an option that would allow feel a minimum negative influence on the EU in general and all MS separately. 


\subsection{EU budget redistribution considering Brexit}

It is important to evaluate, how big the „Brexit deficit“ would be if the UK does not pay any national contributions to the EU budget or the EU does not receive any income from the UK Traditional Own Resources (TOR). Moreover, the EU would not have any commitments and expenses in the UK and the UK overpay refund corrections would automatically be eliminated along with the end of UK overpay refund mechanism. This way, based on the data of 2014-2016 MFF financial reports (European Commission, 2018), the EU would save some 7 billion EUR that are dedicated to the UK projects annually. On the other hand, 3 billion EUR lower budget income would be gathered from the TOR. In addition, the EU would lose 14 billion EUR in the form of direct UK contributions. In total, the EU would lose 10 billion EUR of annual budget income.

Considering the data in MFF financial reports for 2014-2016 (European Commission, 2018), Brexit would decrease the General National Income of the EU by approximately $16.2 \%$ which makes it difficult to adapt the EU budget considering new reality. In this paper, the three main scenarios that could be implemented when making the decision for join budget on the EU level are analysed. These scenarios are based on the review of Brexit effect by Haas and Rubio (2017).

The first scenario describes the Status Quo. In this case, the Status Quo means that if member states decide to maintain the same EU budget as it was until now, the income into the EU budget would have to be increased by 10 billion Euros. Obviously, following the Status Quo scenario, all member states would be required to significantly increase their contributions. However, the impact on net Common Agricultural Policy (CAP) balances would not be divided equally among MS.

The second scenario - CAP3 - assumes the decrease in the EU expenses. Expense reduction may vary depending on which EU strategy would be chosen and which expenditures would be affected. In order to decide, which expenditures and program could face reduced financing, it is important to evaluate the consequences of the fact that the net „saved" sum should be no less than 10 billion EUR per year. Yet another choice is to combine the reduction in the EU expenses and increase in the MS contributions. In this case, it is assumed that a part of the contributions would be reduced on account of the CAP funding. As a compromise, the CAP funding would be reduced by 3 billion Euros each year.

The third scenario assumes a decrease in the CAP expenses by $20 \%$, i.e. scenario CAP10 implies the CAP funding would be reduced by 10 billion Euros.

\section{Methodological approach}

The modelling of possible Brexit impact in Lithuania is based on the abovementioned scenarios. Brexit's impact on CAP funding is evaluated in two stages of the research. The first stage analyses the impact of altered EU funding on the CAP net balances, i.e. a difference is calculated between the contributions to the EU CAP budget of that particular EU MS and that MS received CAP funding. In the second stage, it is predicted, how CAP funding changes if a new order of national contribution to the EU budget would be accepted based on abovementioned scenarios.

The data for calculations are taken from the European Commission budget reports the reports of 2014-2016 MFF (European Commission, 2018) by expense types and income types for separate member states (Table 1).

In order to evaluate the impact of Brexit on CAP funding in Lithuania and the other MS following the Status Quo scenario, the data provided by EC on the EU budget fulfilment 
INTERDISCIPLINARY APPROACH TO ECONOMICS AND SOCIOLOGY

were applied (EU MFF reports).Those data were used to calculate the CAP net balances for all MS including Lithuania (the average values for 2014-2016 were used ${ }^{1}$ ).

Table 1. MFF report part for 2014-2016, Lithuania, mill. EUR

\begin{tabular}{|c|c|c|c|c|}
\hline No. & Article & 2014 & 2015 & 2016 \\
\hline 2 & SUSTAINABLE GROWTH: NATURAL RESOURCES & 624.39 & 528,38 & 721,08 \\
\hline 2.0 .1 & $\begin{array}{l}\text { European Agricultural Guarantee Fund (EAGF) - Market related expenditure and } \\
\text { direct payments }\end{array}$ & 384.34 & 414,68 & 440,63 \\
\hline \multirow[t]{3}{*}{2.0 .10} & $\begin{array}{l}\text { European Agricultural Guarantee Fund (EAGF) - Market related expenditure and } \\
\text { direct payments }\end{array}$ & 384.34 & 414,68 & 440,63 \\
\hline & Direct Aid & 374.11 & 393,74 & 409,89 \\
\hline & Other & 10.23 & 20,94 & 30,74 \\
\hline 2.0 .2 & European Agricultural Fund for Rural Development (EAFRD) & 232.39 & 106,90 & 276,17 \\
\hline 2.0 .3 & $\begin{array}{c}\text { European Maritime and Fisheries Fund (EMFF). Regional Fisheries Management } \\
\text { Organisations (RFMOs) and Sustainable Fisheries Agreements (SFAs) }\end{array}$ & 6.34 & 6,42 & 2,88 \\
\hline 2.0 .31 & European Maritime and Fisheries Fund (EMFF) & 6.34 & 6,42 & 2,88 \\
\hline 2.0 .32 & $\begin{array}{l}\text { Sustainable Fisheries Partnership Agreements (SFAs) and compulsory contributions } \\
\text { to Regional Fisheries }\end{array}$ & 0.00 & 0,00 & 0,00 \\
\hline 2.0 .4 & Programme for the Environment and Climate Action (Life) & 1.33 & 0,35 & 1,29 \\
\hline 2.0.DAG & Decentralised agencies & 0.00 & 0,03 & 0,01 \\
\hline 2.0.OTH & Other actions and programme & 0.00 & 0,00 & 0,00 \\
\hline 2.0.PPA & Pilot projects and preparatory actions & 0.00 & 0,00 & 0,10 \\
\hline 2.0.SPEC & $\begin{array}{l}\text { Actions financed under the prerogatives of the Commission and specific } \\
\text { competences conferred to the Commission }\end{array}$ & 0.00 & 0,00 & 0,00 \\
\hline $\begin{array}{c}\text { TOTAL } \\
\text { EXPENDI } \\
\text { TURE } \\
\end{array}$ & & 1885.9 & 877,2 & $1.477,4$ \\
\hline & VAT-based own resource & 40.3 & 42.9 & 45,3 \\
\hline & GNI-based own resource & 253.6 & 247.2 & 242,6 \\
\hline & UK correction & 26.3 & 25.6 & 28,2 \\
\hline & Retro-active implementation of the 2014 Own Resources Decision - NC & - & - & 12,0 \\
\hline & Lump Sum Reduction Granted for DK, NL, AT \& SE & 0.0 & 0.0 & 2,8 \\
\hline & FSJ adjustment for Denmark, Ireland and the United Kingdom & 0.2 & 0.1 & 0,3 \\
\hline & TOTAL national contribution & 320.4 & 315.8 & 331,3 \\
\hline & Traditional own resources (TOR) $(80 \%)$ & 64.3 & 73.9 & 77,5 \\
\hline & Agricultural duties $(100 \%)$ & 0.0 & 0.0 & 0,0 \\
\hline & Sugar levies $(100 \%)$ & 1.0 & 1.1 & 1,1 \\
\hline & Customs duties (100\%) & 84.7 & 97.7 & 95,8 \\
\hline & Retro-active implementation of the 2014 Own Resources Decision - TOR & 0.0 & 0.0 & 0,0 \\
\hline & Amounts $(20 \%)$ retained as TOR collection costs & -21.5 & -24.9 & $-19,4$ \\
\hline & TOTAL own resources & 384.7 & 389.7 & 408,8 \\
\hline & Gross National Income (GNI), EUR million* & 35202.8 & 35750.7 & 37012,9 \\
\hline & General government expenditure 2014-2016 avg. & & 12983.8 & \\
\hline
\end{tabular}

Source: prepared by the authors, based on Eurostat* and European Commission MFF reports for 2014-2016, (2017).

It should be noted that MS net balances for particular expenses, such as CAP funding, are not provided in the MFF and the whole EU income goes to the joint budget. The balance of a particular expense category can be calculated by comparing the EU MS contributions to

\footnotetext{
${ }^{1}$ The period of 2014-2016 was chosen due to new CAP programming period starting in 2014 (CAP 2014-2020) while the last accurate data available are those for year 2016. Therefore, to ensureminimal uncertainty when evaluating the influence on separate MS CAP balances, the average based on this period is used.
} 
the EU budget and the EU funds that MS receives for a particular expense type in the MFF report. Based on the guidelines for calculating the net balance for a particular expense type (European Parliament, 2017), the net CAP balances are calculated as follows:

$$
\begin{aligned}
& \overline{N B}_{i}^{C A P}=\frac{1}{T} \sum N B_{i t}^{C A P}, \\
& N B_{i t}^{C A P}=T C_{i t}^{C A P^{*}}-E X_{i t}^{C A P}, \\
& T C_{i t}^{C A P^{*}}=T C_{i t}^{*} E X_{t}^{E U}, \\
& E X_{t}^{E U}=E A G F_{t}^{E U}+E A F R D_{t}^{E U}, \\
& T C_{i t}^{*}=\frac{T C_{i t}}{T C_{t}^{E U}},
\end{aligned}
$$

where $t=1,2, \ldots, T$ is the time period (we consider years 2014 to 2016), $i$ is the index of the EU MS; $N B_{i t}^{C A P}$ - the netCAP balance for MS $i$ during year $t ; \overline{N B}_{i}^{C A P}$ - the average CAP net balance for EU MS $i$ during the period analysed; $T C_{i t}^{C A P^{*}}$ is the weighed net contribution to CAP of EU MS $i$ in year $t$; $E X_{i t}^{C A P}-$ CAP expenses in year $t$ of MS $i$; $E X_{t}^{E U}-$ the EU CAP expenses in year $t$ which include European Agricultural Guarantee Fund (EAGF), i. e. market related expenditure, direct payments and European Agricultural Fund for Rural Development (EAFRD); $T C_{i t}$ - the net national contribution of EU MS $i$ in year $t ; T C_{t}^{E U}$-sum of the net general national contributions in year $t$.We further normalize the results by the land area. In order to evaluate the CAP net balances per utilized agricultural area (UAA), $\overline{N B}_{i}{ }^{C A P}$ is further divided by the corresponding $\mathrm{UAA}^{2}$ in MS $i$.

In order to evaluate the CAP net balances per utilized agricultural area (UAA), $\overline{N B}_{i}^{C A P}$ is further divided by the corresponding $\mathrm{UAA}^{2}$ in MS $i$.

To evaluate the possible impact of Brexit on CAP net balances following the 3 scenarios, several additional calculations were made following the recommendations of European Parliament (2017) and Matthews (2017a, 2017b) - UK rebate was eliminated and the net contributions of the UK were divided among member states taking their GNI into consideration. It allowed forecast the change of commitments of EU MS if the UK rebate ${ }^{3}$ and the so-called "rebate on rebate"4 impacting the contributions of Austria, Germany, Netherlands and Sweden is eliminated. These calculations are necessary as in the case when all MS increase their contributions proportionally, the contributionsof rebate MS would increase significantly more than these in others. Therefore, with the assumption that expenses in ,new“(those that joined the EU after 2004) MS to the second CAP pillar are not included in the UK rebate, two measures can be calculated: (1) to what extend each MS have to contribute on rebate funding according to the existing rules and (2) how the burden would be distributed if GNI proportions were invoked instead. The difference between (1) and (2) can be both negative and positive, but in either occasion, the decision itself would allow to eliminate all UK rebates. In that case, the net contribution of the UK would be distributed among MS with

\footnotetext{
${ }^{2}$ Eurostat data for 2013

${ }^{3}$ The UK rebate (or UK correction) is a financial mechanism that reduces the United Kingdom's contribution to the EU budget in effect since 1985. It is a complex calculation which equates to approximately $66 \%$ of the UK's net contribution - the amount paid by the UK into the EU budget less EU expenditure in the UK (Council, 1985).

${ }^{4}$ Rebate on the UK rebate (see Footnote 3) is applied to Austria, Germany, Netherlands and Sweden. Based on the averages of 2014-2016 these countries contributed up to $2 \%$ of GNI-based own resource for the UK rebate while other EU MS contributed 10-12\% on average.
} 
GNI taken into consideration as a limiting source of income to the EU budget. Considering all the discussed aspects, the changes of CAP funding based on scenarios are further presented.

\section{Conducting research and results}

Table 2 illustrates CAP net balances of the EU MS on 2014-2016 average. MS can be divided into 2 groups: the first (places 1 to 15) - positive CAP net balance group, i.e. beneficiaries and the second (places 16 to 28) - negative CAP net balance group (donor MS).

Table 2.EU MS CAP net balance for 2014-2016 (average), Mill. EUR

\begin{tabular}{llcclc}
\hline Nr. & Member states (I group) & Mill. EUR & Nr. & Member states (II group) & Mill. EUR \\
\hline 1. & Poland & $3.123,9$ & 16. & Cyprus & $-3,1$ \\
\hline 2. & Greece & $2.095,4$ & 17. & Denmark & $-9,9$ \\
\hline 3. & Romania & $1.970,4$ & 18. & Finland & $-23,0$ \\
\hline 4. & Spain & $1.821,4$ & 19. & Malta & $-23,4$ \\
\hline 5. & Hungary & $1.336,9$ & 20. & Luxembourg & $-93,8$ \\
\hline 6. & Bulgaria & 837,5 & 21. & Austria & $-118,7$ \\
\hline 7. & Ireland & 729,1 & 22. & Sweden & $-659,6$ \\
\hline 8. & Portugal & 550,2 & 23. & France & $-1.025,7$ \\
\hline 9. & Czech Republic & 526,3 & 24. & Belgium & $-1.190,4$ \\
\hline 10. & Lithuania & 466,6 & 25. & Netherlands & $-1.394,3$ \\
\hline 11. & Slovakia & 251,3 & 26. & Italy & $-1.544,5$ \\
\hline 12. & Latvia & 27. & United Kingdom & $-2.944,6$ \\
\hline 13. & Estonia & 164,5 & 28. & Germany & $-5.060,6$ \\
\hline 14. & Slovenia & 107,9 & & & \\
\hline 15. & Croatia & 77,0 & & & \\
\hline
\end{tabular}

Source: prepared by the authors based on European Parliament (2017) and Matthews, 2017a.

Five biggest CAP net balance beneficiaries, which are Poland, Greece, Romania, Spain and Hungary, in absolute numbers, receive a total of 10 billion EUR that accounts positive net balance from 1.3 to 3.1 billion EUR for each. According to these calculations, Lithuania ranks10th place and falls into the group of beneficiaries with a positive CAP net balance of 466.6 million EUR. Amongst the biggest CAP netcontributors, i.e. donor MS with negative CAP net balances are Germany, UK and Italy. Their joint annual CAP net contribution CAP is 5.1, 2.9 and 1.5 billion EUR respectively.

Based on the fact that the major part CAP payments are calculated per UAA ha, this aspect in particular is very important in the Brexit evaluations. Nevertheless CAP net balances may both be strongly positive or negative in their absolute value, they are able to change in comparison with UAA of MS and in turn regroup the position of MS. Thus, it is important to evaluate CAP net balances per 1 ha of UAA. With regard to the results obtained, the composition of two abovementioned groups actually has changed (Graph 1).

According to Graph 1 the top 5 biggest beneficiaries based on CAP net balance per 1 ha of UAA changed both in structure and ranking. Now it consists of Greece, Hungary, Poland, Bulgaria and Lithuania with 431.4 EUR/ha to $163.1 \mathrm{EUR} / \mathrm{ha}$ respectively. The result shows that Lithuania jumped from 10th place to 5th while Greece and Hungary outran Poland. Although in absolute values of CAP net balances Germany is in a very bad spot of being the main donor, compared to the relative UAA, it ends up in a pretty good situation compared to other donor MS and ranks the fifth place from the bottom. 


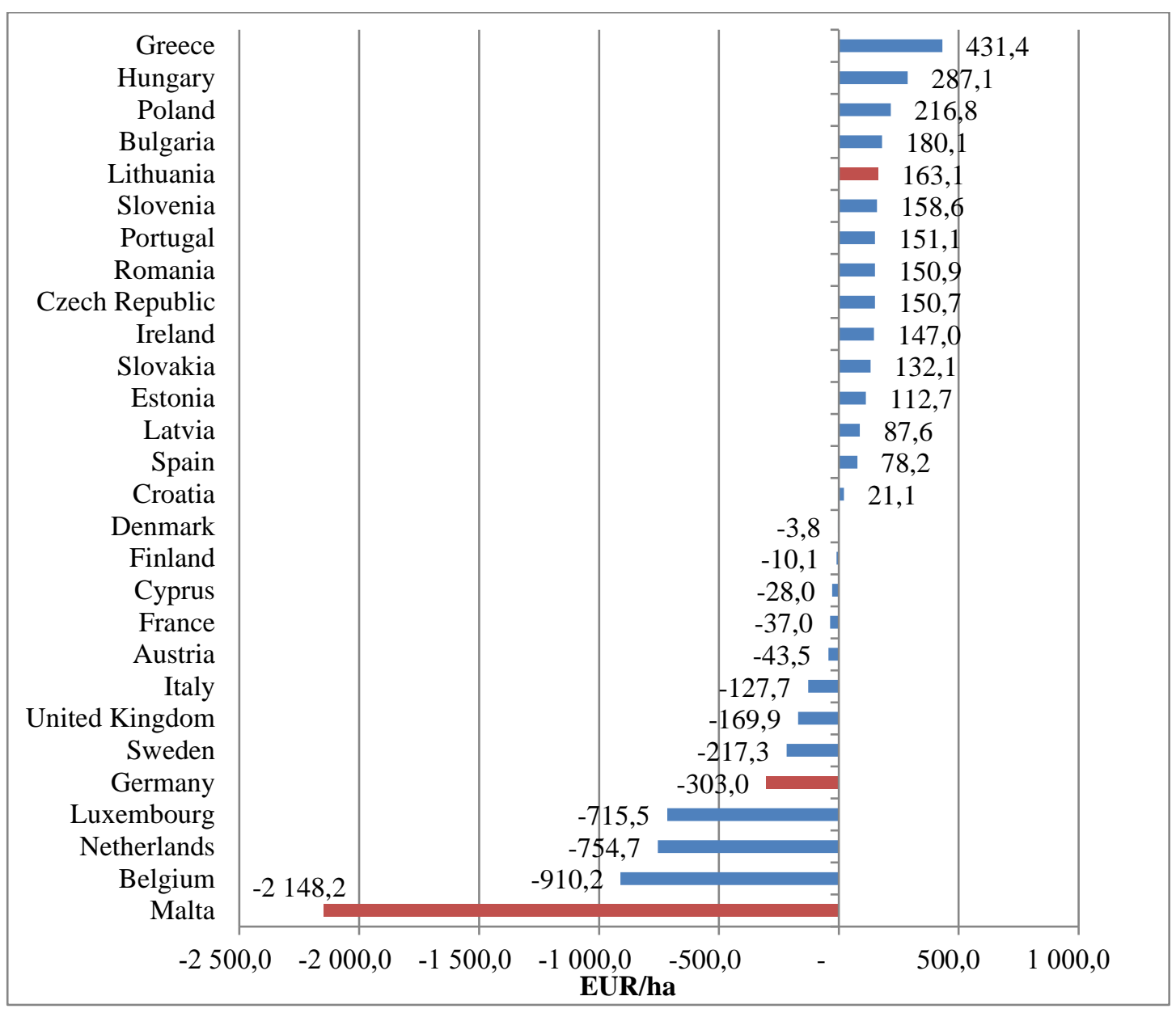

Graph 1. EU MS CAP net balance per 1 ha of UAA

Source: prepared by the authors base on European Parliament, 2017 and Matthews, 2017a *Average for 2014-2016.

Based on these calculations, the worst situation would be that of Malta, Belgium and the Netherlands. Their negative CAP net balance per 1 ha of UAA would be from 2148.2 EUR/ha to 754.7 EUR/ha respectively.

\subsection{Realization of scenario Status Quo}

If the same level of expenses of CAP would be attempted to maintain after Brexit, i. e. Status Quo scenario would prevail, 3 additional billion EUR would have to flow into CAP financial line of MFF every year. In that case, additional contributions from all MS would be made by using GNI resources. Such increase in contribution would lead to a decreased CAP netbalance for almost all MS. However, not all of EU MS budgets would be affected equally. As mentioned before, Austria, Germany, Netherlands and Sweden would lose the benefit of,,rebate on UK rebate“.

In general, a steeper increase in contributions expands the already existing imbalance between donors and beneficiaries of CAP net contribution. According to Status Quo scenario, negative Germany's CAP net balance would increase from 5.0 to 6.6 billion EUR (a change of 1.6 billion EUR), that of France - from 1025.7 to 1.2 billion EUR (a change of 0.2 billion EUR) (Table 3). 
INTERDISCIPLINARY APPROACH TO ECONOMICS AND SOCIOLOGY

Table 3.Changes of the CAP net balances according to Status Quo scenario

\begin{tabular}{llllll}
\hline \multicolumn{1}{c}{ Member state } & Mill. & \multicolumn{1}{c}{$\begin{array}{c}\text { Member } \\
\text { state }\end{array}$} & $\begin{array}{c}\text { Mill. } \\
\text { EUR }\end{array}$ & \multicolumn{1}{c}{ Member state } & Mill. EUR \\
\hline 1. Malta & $-0,9$ & 10. Slovakia & $-6,1$ & 19. Belgium & $-36,2$ \\
\hline 2. Estonia & $-1,8$ & 11. Hungary & $-9,5$ & 20. Poland & $-37,1$ \\
\hline 3. Latvia & $-2,1$ & 12. Greece & $-11,7$ & 21. Spain & $-86,7$ \\
\hline 4. Cyprus & $-2,1$ & 13. Republic & $-12,9$ & 22. Italy & $-148,9$ \\
\hline 5. Lithuania & $-3,2$ & 14. Romania & $-13,6$ & 23. Austria & $-156,5$ \\
\hline 6. Slovenia & $-3,3$ & 15. Portugal & $-14,8$ & 24. France & $-187,9$ \\
\hline 7. Croatia & $-3,5$ & 16. Ireland & $-15,6$ & 25. Sweden & $-221,5$ \\
\hline 8. Luxembourg & $-3,5$ & 17. Finland & $-17,0$ & 26. Netherlands & $-374,6$ \\
\hline 9. Bulgaria & $-4,3$ & 18. Denmark & $-22,0$ & 27. Germany & $-1.547,5$ \\
\hline
\end{tabular}

Source: prepared by the authors based on MFF reports (2014-2016) and European Parliament, 2017.

At the same time, Poland's CAP net balance wouldn't almost change and make up 3.1 billion EUR (sum of budget in first place of Table 2 and $20^{\text {th }}$ place of Table 3 ). In Lithuanian case, the CAP net balance would only decrease by 3.2 million EUR. In spite of that, it is important to emphasize that the calculated amounts only make up a small part of governmental sector expenses. Even in rebate MS, i.e. those that benefit from returns from UK rebate, the net balance change would amount to only $0.1 \%$ of all general government expenditure (GGE). Meanwhile, in Lithuania's case, this would amount to $0.02 \%$ of GGE (Graph 2).

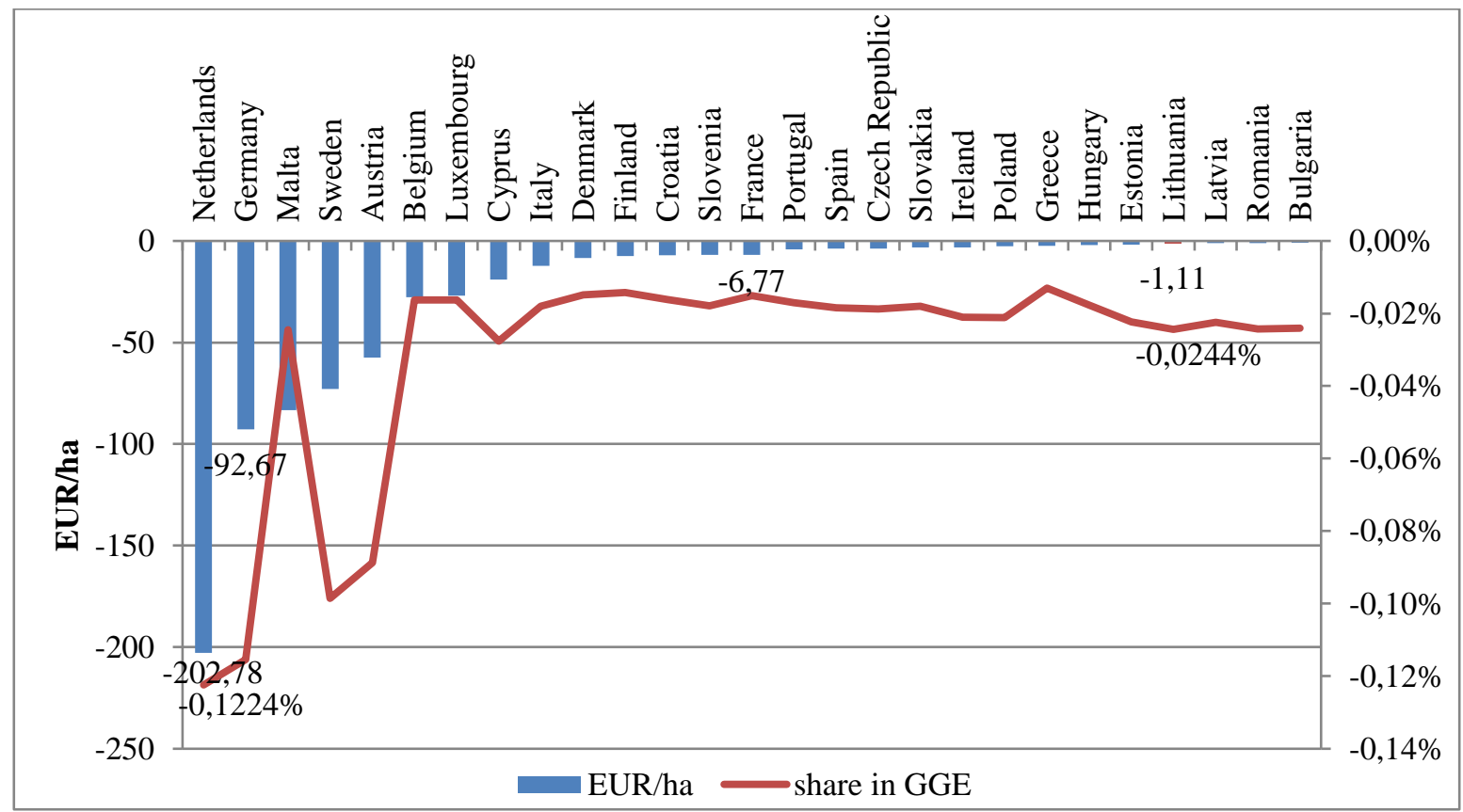

Graph 2. Changes in the CAP net balances per 1 UAA ha according to Status Quo scenario

Source: prepared by the authors based on Eurostat, 2017, MFF reports (2014-2016) and European Parliament, 2017.

Evaluating the impact of Brexit Status Quo scenario for CAP net balances change considering the dimension of utilized area, Netherlands would lose the most. CAP net balance per 1 UAA ha would decrease by 202.8 EUR/ha while France would rank up, from 24th place 
(see Table 3) to 13th with a loss of less than 7 EUR/ha. There is no significant changes in Lithuania with CAP net balance loss of $1.11 \mathrm{EUR} / \mathrm{ha}$ (ranking 4th place).

\subsection{Implementation of CAP3 scenario}

Reduction of EU expenses which is described in CAP3 scenario raises a higher burden of adaptation for the beneficiaries of positive CAP net balance. The 3 billion EUR which replace the Britain's CAP net contribution would decrease CAP net balance of Poland and Greece by 213 and 131 million EUR respectively. Some net contribution donors such as Luxembourg and Belgium would see a small positive improvement of CAP net balance but would be affected negatively nonetheless. Germany's CAP net balance would increase by 600 million EUR more in comparison to the Status Quo scenario and CAP net balance change would be -964.3 million EUR while Lithuania's CAP net balance would decrease by almost 30 million EUR (12th place) which is 10 times more than in the case of Status Quo (5th place). It is important to emphasize that in some cases the reduced CAP contribution would be higher than the loss of EU funding (Table 4).

Table 4. Changes of the CAP net balances according to CAP3 scenario

\begin{tabular}{|c|c|c|c|c|c|}
\hline Member state & Mill. EUR & $\begin{array}{l}\text { Member } \\
\text { state }\end{array}$ & Mill. EUR & Member state & Mill. EUR \\
\hline 1. Belgium & 11,6 & 10. Finland & $-16,0$ & 19. Romania & $-123,2$ \\
\hline 2. Luxembourg & $-0,6$ & 11. Denmark & $-16,1$ & 20. Austria & $-128,6$ \\
\hline 3. Malta & $-0,7$ & 12. Lithuania & $-29,6$ & 21. Greece & $-131,2$ \\
\hline Cyprus & $-10,0$ & Czech & $-45,5$ & & \\
\hline 4. & & 13. Republic & & 22. Sweden & $-133,9$ \\
\hline 5. Croatia & $-10,5$ & 14. Portugal & $-45,5$ & 23. Netherlands & $-190,2$ \\
\hline 6. Slovenia & $-10,6$ & 15. Bulgaria & $-48,2$ & 24. France & $-192,9$ \\
\hline 7. Estonia & $-10,6$ & 16. Ireland & $-53,6$ & 25. Poland & $-214,3$ \\
\hline 8. Latvia & $-10,7$ & 17. Hungary & $-80,4$ & 26. Spain & $-219,6$ \\
\hline 9. Slovakia & $-16,0$ & 18. Italy & $-96,4$ & 27. Germany & $-964,3$ \\
\hline
\end{tabular}

Source: prepared by the authors based on MFF reports (2014-2016) and European Parliament, 2017.

It can be seen that the higher the positive CAP net balance is in MS, the higher negative impact on net balances the Brexit can cause following this scenario.

The situation changes if the mentioned loss is evaluated through the prism of CAP net balance per 1 UAA ha. According to CAP3 scenario the highest negative impact would be in the Netherlands but only half as big (-102.9 EUR/ha) as in Status Quo scenario (202.8 EUR/ha). CAP3 scenario allows create conditions for all EU MS to suffer losses of no more than 100 EUR per 1 ha. Countries such as Belgium, France, Italy and Spain would lose even less than Lithuania with change of negative CAP net balance equal to10.3 EUR/ha (Graph 3).

Although the loss of net financing of CAP in Lithuania is relatively low, the CAP net balance change is the second worst in comparison to share of all GGE and amounts to $0.23 \%$. The highest share of GGE would be in Bulgaria $-0.27 \%$. 
INTERDISCIPLINARY APPROACH TO ECONOMICS AND SOCIOLOGY

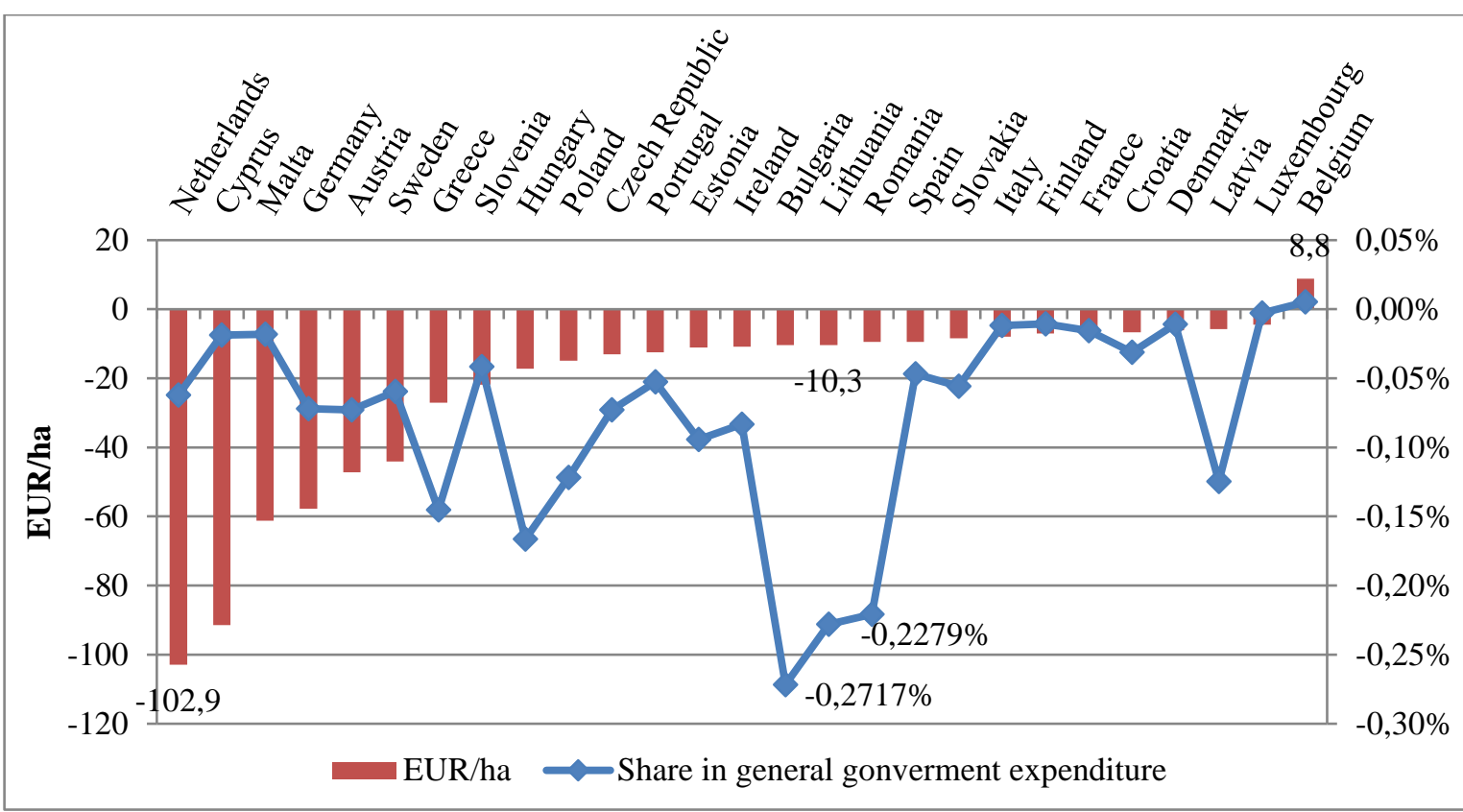

Graph 3.Changes in the CAP net balances per 1 UAA ha according to CAP3 scenario.

Source: prepared by the authors based on Eurostat, MFF reports (2014-2016), 2017 and European Parliament, 2017.

\subsection{Implementation of CAP10 scenario}

Following CAP10 scenario, i.e. if the decrease in contributions of 10 billion EUR is reduced by CAP expenses, the impact on MS would be completely opposite in comparison to Status Quo scenario. According to CAP10 scenario, the MS that are big CAP net contributors would have the biggest benefit. For the majority of former UK rebate MS, i.e. Germany, Netherlands, Austria and Sweden, savings from reduced contributions would outweigh the distribution of EU funds. - Meanwhile, most net beneficiaries would pay a little less to the CAP budget, but would receive significantly lower payments. The CAP net balance of Poland would decrease by a fifth (663.2 million EUR) (Table 5).

Table 5.Changes of the CAP net balances according to CAP10 scenario

\begin{tabular}{|c|c|c|c|c|c|}
\hline Member state & Mill. EUR & MS & Mill. EUR & MS & Mill. EUR \\
\hline 1. Belgium & 162,9 & 10. Denmark & $-9,3$ & 19. Czech Rep. & $-120,2$ \\
\hline 2. Italy & 128,9 & 11. Slovenia & $-18,9$ & 20. Portugal & $-125,8$ \\
\hline 3. Netherlands & 111,7 & 12. Finland & $-20,1$ & 21. Bulgaria & $-168,9$ \\
\hline 4. Luxembourg & 15,3 & 13. Estonia & $-23,3$ & 22. Ireland & $-170,4$ \\
\hline 5. Malta & 3,1 & 14. Latvia & $-35,8$ & 23. Hungary & $-275,4$ \\
\hline 6. Cyprus & $-2,2$ & 15. Slovakia & $-56,3$ & 24. Romania & $-394,7$ \\
\hline 7. Sweden & $-5,5$ & 16. France & $-76,3$ & 25. Greece & $-426,3$ \\
\hline 8. Germany & $-7,0$ & 17. Lithuania & $-93,2$ & 26. Spain & $-484,2$ \\
\hline 9. Croatia & $-9,0$ & 18. Austria & $-96,7$ & 27. Poland & $-663,2$ \\
\hline
\end{tabular}

Source: prepared by the authors based on MFF reports (2014-2016) and European Parliament, 2017.

If this particular scenario would be implemented, CAP net balance in Lithuania would decrease by 93.2 million EUR, which is 90 million EUR less in comparison to Status Quo scenario. 
In the discussed case, Lithuania would rank at 17th place which is 12 places lower compared to the Status Quo scenario. For MS such as Belgium, Italy, Netherlands, Luxembourg and Malta, this scenario would be even beneficial than the current situation without Brexit. (Graph 4).

Even more interesting is the situation of evaluating CAP net balance per 1 UAA ha

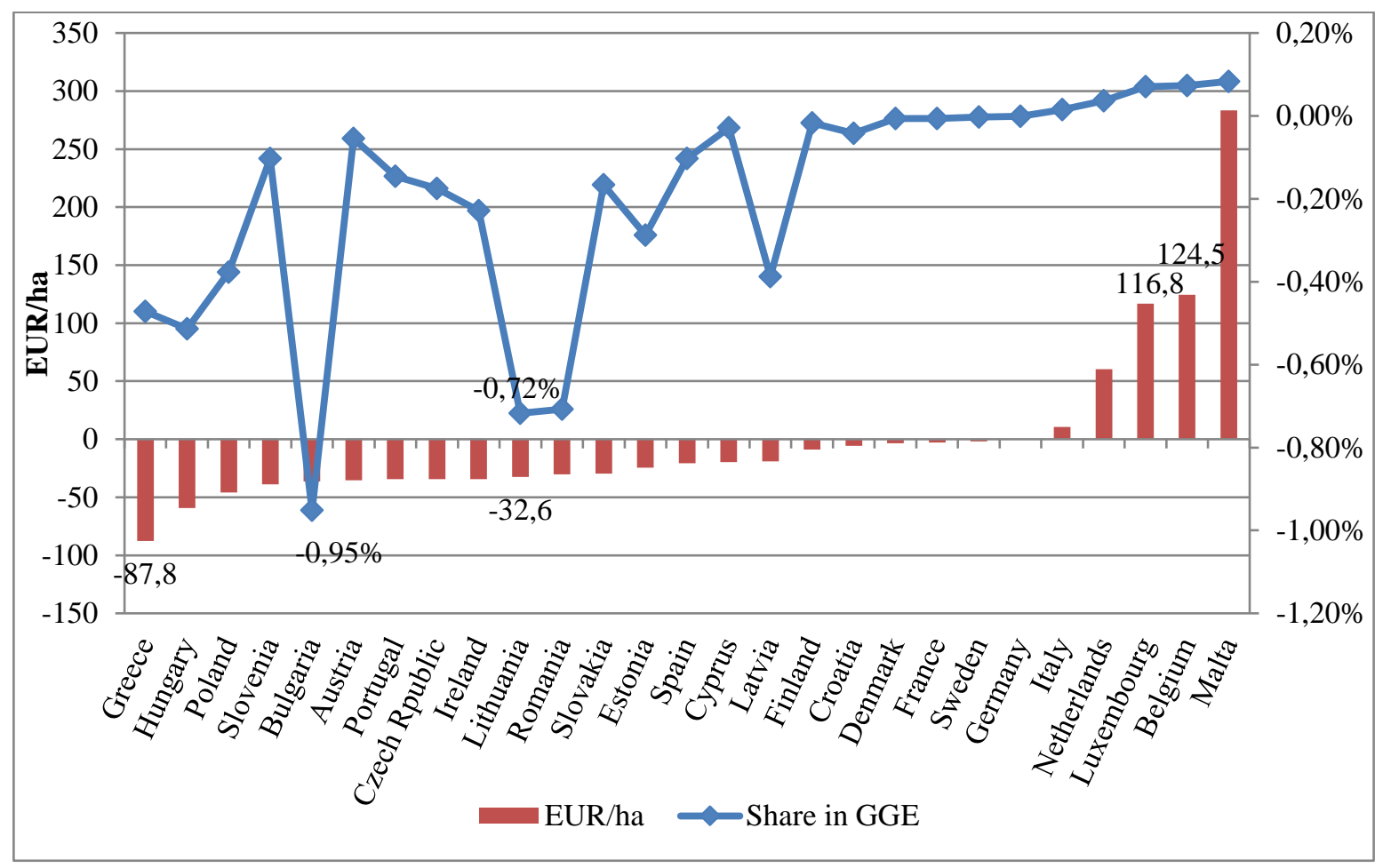

Graph 4. Changes in the CAP net balances per 1 UAA ha according to CAP10 scenario

Source: prepared by the authors based on Eurostat (2017), MFF reports (2014-2016) and European Parliament (2017).

Evaluating the impact of CAP10 scenario on the CAP net balance change per 1 ha, Lithuania ranks one place lower - from 17th to 18th when compared to the absolute value of CAP net balance change. However, evaluation through this variable rather than absolute values is seems to be more attractive for Spain, which ranks at 14 th place from 25 th. On the other hand, this evaluation brings Slovenia to the 24 th place from $11^{\text {th }}$, which means that not so strong loses in absolute values amounts to deep losses when compared to 1 ha of UAA. In addition, the most negative impact of this Brexit scenario would be in Bulgaria, Lithuania and Romania and according to the made calculations would amount to more than $0.7 \%$ of GGE (when calculating the ratio between the CAP net balance change and GGE) (Graph 4).

All three scenarios show that Brexit may have a significant impact on many MS. However, evaluating the situation from the perspective of Lithuania, Status Quo scenario, i.e. increasing the contributions to the EU budget, would be the most beneficial (Table 6), calculations are based on the average of MFF for 2014-2016). In the mentioned case, losses would be minimal. 
Table 6. The impact of the various Brexit scenarios on CAP net balances and received payments from the EU CAP as well as for the financing of the CAP pillar I and II in Lithuania, Mill. EUR

\begin{tabular}{lcccc}
\hline Scenario & $\begin{array}{c}\text { CAP net balance } \\
\text { change, Mill. } \\
\text { EUR }\end{array}$ & $\begin{array}{c}\text { Change in received } \\
\text { payments from EU } \\
\text { CAP, Mill. EUR }\end{array}$ & $\begin{array}{c}\text { Change on financing } \\
\text { of CAP I pillar, Mill. } \\
\text { EUR }\end{array}$ & $\begin{array}{c}\text { Change on } \\
\text { financing of CAP } \\
\text { II pillar, Mill. } \\
\text { EUR }\end{array}$ \\
\hline Status Quo & $-3,2$ & - & - & - \\
\hline CAP3 & $-29,6$ & $-31,1$ & $-20,8$ & $-10,3$ \\
\hline CAP10 & $-93,2$ & $-103,5$ & $-69,2$ & $-34,3$ \\
\hline
\end{tabular}

Source: prepared by the authors based on Eurostat (2017), MFF reports (2014-2016) and European Parliament (2017).

Taking into account the estimated impact of Brexit on the basis of the three different scenarios, based on the 2014-2016 MFF, the relative impact on the change the CAP net balance and financing payments from the EU CAP has been established (Table 7).

Table 7. The impact of the various Brexit scenarios on the net balance of the CAP and the financing of payments from the EU CAP in Lithuania, \%

\begin{tabular}{lcc}
\hline Scenario & CAP net balance change, $\%$ & Change in financing of payments from the EU CAP, \% \\
\hline Status Quo & $-0,68$ & - \\
\hline CAP3 & $-6,34$ & $-5,04$ \\
\hline CAP10 & $-19,97$ & $-16,74$ \\
\hline
\end{tabular}

Source: prepared by the authors based on Eurostat (2017), MFF reports (2014-2016) and European Parliament (2017).

The determined shares allow making assumptions about the possible impact on the financing of the main CAP measures - direct payments (DP) and Rural Development Programme (RDP) measures in Lithuania in financial years 2018-2020 (Table 8).

Table 8. The impact of various Brexit scenarios on financingof DP and RDP measures in Lithuania, in 2018-2020

\begin{tabular}{lccc}
\hline \multicolumn{1}{c}{ Scenario and budget change } & $\begin{array}{c}2018 \\
\text { (Thou. EUR) }\end{array}$ & $\begin{array}{c}2019 / 2020 \\
\text { (Thou. EUR) }\end{array}$ & $\begin{array}{c}2018-2020 \\
\text { (Thou. EUR) }\end{array}$ \\
\hline $\begin{array}{l}\text { By Regulation (EU) No 1307/2013 and No } \\
1305 / 2013\end{array}$ & 492049 & 517028 & 282539 \\
\hline Status Quo, thou. EUR & 492049 & 517028 & 282539 \\
\hline CAP3, thou. EUR & 467264 & 490985 & 268307 \\
\hline CAP10, thou. EUR & 409679 & 430476 & 235241 \\
\hline Difference between CAP3 and Status Quo & -24785 & -26043 & -14232 \\
\hline Difference between CAP10 and Status Quo & -82370 & -86552 & -47298 \\
\hline
\end{tabular}

Source: prepared by the authors based on Eurostat (2017) and European Parliament (2017).

Summing it up, it should be said that the reduction of EU budget due to Brexit would mean a decrease in support for Lithuanian CAP funding. Such decrease could make up as much as $16.7 \%$ of current budget. 


\section{Conclusion}

This paper looked into the effects of the Brexit on the EU CAP. Specifically, the changes in the funding were analysed. The three scenarios of Brexit were discussed: 1) balancing of CAP financing, increasing the budget by 3 billion EUR (Status Quo scenario); 2) reduction of CAP financing by 3 billion EUR - the CAP3 scenario; and 3) reduction of CAP financing by 10 billion EUR - the CAP10 scenario. The scenarios were evaluated in two perspectives: by their effect on the CAP net balance change and the impact on the CAP net balance change per 1 UAA ha.

The case of Lithuania was analysed along with the other MS. Assessing the impact of the scenarios on the financing of Lithuanian, it was determined that the least impact on Lithuania's CAP financing and CAP net balance change would have the scenario in which the contributions to the EU budget would be increased. Furthermore, it was shown that the reduction of contributions to CAP budget would lead to a negative impact on the CAP net balance in Lithuania: following the CAP3 scenario, the CAP net balance would decrease by $6.34 \%$ while following CAP10 this figure would reach $19.97 \%$ while the received EU payments for financing CAP measures would decrease by 5.04 and $17.74 \%$ respectively. In the case of Status Quo scenario, EU CAP financing in Lithuania would not change and remain the same as set in the multiannual financial framework while the CAP net balance would decrease by only $0.68 \%$.

\section{References}

Bachtler, J., \& Mendez, C. (2016). EU Cohesion Policy and European integration: The dynamics of EU budget and regional policy reform. Routledge.

Bartolini, F., \& Viaggi, D. 2013. The Common Agricultural Policy and the Determinants of Changes in EU Farm Size. Land Use Policy, 31, 126-133.

Bateman, I. J., \& Balmford, B. (2018). Public funding for public goods: A post-Brexit perspective on principles for agricultural policy. Land Use Policy, 79, 293-300.

Bergin, A., Garcia-Rodriguez, A., Morgenroth, E. L., \& Smith, D. (2017). Modelling the Medium-to Long-Term Potential Macroeconomic Impact of Brexit on Ireland. The Economic and Social Review, 48(3, Autumn), 305-316.

Boulanger, P., \&Philippidis, G. (2015). The End of a Romance? A Note on the Quantitative Impacts of a 'Brexit'from the EU. Journal of Agricultural Economics, 66(3), 832-842.

Bruno, R., Campos, N., Estrin, S., \& Tian, M. (2016). Technical Appendix to 'The impact of Brexit on foreign investment in the UK'Gravitating towards Europe: an econometric analysis of the FDI effects of EU membership. Center for Economic Performance, London School of Economics and Political Science, London.

Busch, B., \& Matthes, J. (2016). Brexit-the economic impact: A meta-analysis (No. 10/2016). IW-Report.

Carney, M. (2016) Uncertainty, the economy and policy. Retrieved from https://www.bis.org/review/r160704c.pdf

Council, 1985. Council decision of 7 May 1985 on the Communities' system of own resources (85/257/EEC, Euratom). Official journal of the European Communities (14.05.85)

Culkin, N., \& Simmons, R. (2019). Shock Therapy and Entrepreneurial Flare\# Brexit. International Journal of Entrepreneurial Behavior\& Research.

Darvas, Z., \& Wolff, G. B. (2018). Rethinking the European Union's post-Brexit budget priorities. Bruegel Policy Brief ISSUE 1| MARCH 2018.

Darvas, Z., \& Wolff, G. B. (2018). What budget for the EU?-Principles, spending priorities and the impact of Brexit. 
Ebell, M., \& Warren, J. (2016). The long-term economic impact of leaving the EU. National Institute Economic Review, 236(1), 121-138.

European Commission (2016). Consolidated Annual Accounts of the European Union 2015. Brussels, 11.7.2016. COM (2016) 475 final.

European Commission (2017a). Position paper "Essential Principles on Financial Settlement", TF50 (2017) 2/2 - Commission to UK, 12 June 2017. Accessible on the internet: https://ec.europa.eu/commission/publications/position-paper-essential-principlesfinancial-settlement_en

European Commission (2017b). White paper on the future of Europe and the way forward. Reflections and scenarios for the EU27. Accessible on the internet: https://ec.europa.eu/commission/white-paper-future-europe-reflections-and-scenarioseu27_en

European Commission, 2018. Budget. Multiannual Financial Framework budget in figures. Interactive: EU expenditure and revenue 2014-2020. Accessible on the internet: http://ec.europa.eu/budget/figures/interactive/index_en.cfm

European Council (2017). Council (Art 50) authorises the start of Brexit talks and adopts negotiating directives. Brexit: Negotiating directives - 22 May._Brussels, 22 May 2017. Accessible on the internet: http://www.consilium.europa.eu/media/21766/directives-forthe-negotiation-xt21016-ad01re02en17.pdf

European Parliament (2017). Research for AGRI Committee - Possible impact of Brexit on the EU budget and, in particular, CAP funding.

Europos Komisija (2017). Komisijos komunikatas Europos vadovųtarybai (50 straipsnis) dėlderybųsu Jungtine Karalystepagal Europos Sajungossutarties 50 straipsnịpažangos. COM (2017). 784 final. Briuselis, $2017 \quad 12$ 08. Retrieved from https://ec.europa.eu/transparency/regdoc/rep/1/2017/lt/com-2017-784-f1-lt-main-part1.pdf.

Financial Times (2017). Brexit timeline: Key dates in UK's divorce with EU. June 14, 2017. Retrieved from https://www.ft.com/content/64e7f218-4ad4-11e7-919a-1e14ce4af89b.

Golab A., Jie F., Powell R., \& Zamojska, A. (2018). Cointegration between the European Union and the selected global markets following Sovereign Debt Crisis. Investment Management and Financial Innovations, 15(1), 35-45. doi:10.21511/imfi.15(1).2018.05

Grant, W. (2018). Brexit and agriculture. In Routledge Handbook of the Politics of Brexit, 108-118. Routledge.

Haas, J., \& Rubio, E. (2017). Brexit and the EU budget: Threat or opportunity. Jacques Delors Institute Policy Paper, 183.

Helm, D. (2017). Agriculture after brexit. Oxford Review of Economic Policy, 33(suppl_1), S124-S133.

Kierzenkowski, R., Pain, N., Rusticelli, E., \& Zwart, S. (2016). The economic consequences of Brexit.

Kiss, J. 2011. Some Impacts of the EU Accession on the New Member States' Agriculture. Eastern Journal of European Studies, 2(2), 49-60.

Kozhukhivska, R., Kulbitsky, V., Kyryliuk, I., Maliuga, L. and Podzigun, S. (2018). Managing the efficiency of enterprises based on assessment of the land resource potential. Problems and Perspectives in Management, 16(2), 164-178. doi: $10.21511 / \mathrm{ppm} .16(2) .2018 .15$

Lawless, M., \&Morgenroth, E. L. (2019). The Product and Sector Level impact of a hard Brexit across the EU. Contemporary Social Science, 1-19.

Lizińska, W., Marks-Bielska, R., \& Babuchowska, K. (2017). Intervention on the agricultural land market in relation to the end of the transitional period for purchasing agricultural 
land by foreigners. Equilibrium. Quarterly Journal of Economics and Economic Policy, 12(1), 171-183. doi:10.24136/eq.v12i1.9.

Matthews, A. (2016). The Potential Implications of a Brexit for Future EU Agri-food Policies. EuroChoices, 15(2), 17-23.

Matthews, A. (2017a). Impact of Brexit on CAP budget net balances for remaining Member States. CAP reform EU. Retrieved from www.capreform.eu

Matthews, A. (2017b). Which EU countries will bear the brunt of a hard Brexit? July 31, 2017. Retrieved from www.capreform.eu

McMahon, J. (2018). Brexit, trade and agriculture: waiting for answers. Journal of International Trade Law and Policy, 17(1/2), 19-33.

Nunez-Ferrer, J., \& Rinaldi, D. (2016). The Impact of Brexit on the EU Budget: A noncatastrophic event. CEPS Policy Brief, (347).

Owen, E., \& Walter, S. (2017). Open economy politics and Brexit: insights, puzzles, and ways forward. Review of international political economy, 24(2), 179-202.

Reiff, M., Surmanová, K., Balcerzak, A. P., \& Pietrzak, M. B. (2016). Multiple criteria analysis of European Union agriculture. Journal of international studies, 9(3), 62-74.

Sampson, T. (2017) Brexit: The Economics of International Disintegration. Journal of Economic Perspectives, 31(4), 163-84. doi:10.1257/jep.31.4.163.

Simionescu, M., Bilan, Y., Smrčka, L., \& Vincúrová, Z. (2017). The effects of European economic integration and the impact of Brexit on the UK immigrants from the CEE countries. E+ M Ekonomie a Management, XX(1), 29-47.

Simionescu, M. (2018). The impact of Brexit on the UK inwards FDI. Economics, Management and Sustainability, 3(1), 6-20. doi:10.14254/jems.2018.3-1.1

Sorace, M., \& Hobolt, S. B. (2018). Brexit identities play a role in how people view the economy and immigration. LSE Brexit.

Swinbank, A. (2016). Brexit or Bremain? Future options for UK agricultural policy and the CAP. EuroChoices, 15(2), 5-10.

Szczepaniak, I. (2018). Comparative advantages in Polish export to the European Union food products vs selected groups of non-food products. Oeconomia Copernicana, 9(2), 287-308. doi:10.24136/oc.2018.015.

Treaty, L. (2012). Treaty on European Union and the Treaty on the Functioning of the European Union, Consolidated version of the Treaty on the Functioning of the European Union - Protocols - Annexes - Declarations annexed to the Final Act of the Intergovernmental Conference which adopted the Treaty of Lisbon. Official Journal C 326, 26/10/2012 P. $0001-0390$.

Whyman, P. B., \& Petrescu, A. I. (2017). The economics of Brexit: A cost-benefit analysis of the UK's economic relationship with the EU. Springer.

Vitunskiene, V., \& Serva, E. (2015). Shifts in Lithuania's agri-food industry export competitiveness: a comparative analysis versus high- and medium-high technology manufacturing industries. Oeconomia Copernicana, 6(1), 7-31. doi:10.12775/OeC.2015.001. 